\title{
Corrigendum
}

\section{Like birds of a feather: the cultural origins of Iberian geological cooperation and the European Geological Map of 1896 - Corrigendum}

\author{
JESÚS CATALÁ-GORGUES AND ANA CARNEIRO
}

doi:10.1017/S0007087411000306, published by Cambridge University Press, 18 April 2011

It is regretted that the originally published paper (Catala-Gorgues and Carneiro, 2011) contained an error, Figures 1 and 2 were transposed. We apologize for this oversight.

\section{References}

JESÚS CATALÁ-GORGUES AND ANA CARNEIRO, Like birds of a feather: the cultural origins of Iberian geological cooperation and the European Geological Map of 1896, BJHS (2011), published by Cambridge University Press, 18 April 2011, doi: 10.1017/S0007087411000306 